\title{
Hospitals with and without neurosurgery: a comparative study evaluating the outcome of patients with traumatic brain injury
}

\author{
Aimone Giugni ${ }^{1 \dagger}$, Lorenzo Gamberini ${ }^{1 \dagger}$, Greta Carrara², Luca Antiga33, Obou Brissy², Virginia Buldini', \\ Italo Calamai ${ }^{4}$, Akos Csomos ${ }^{5}$, Alessandra De Luca ${ }^{6}$, Enrico Ferri ${ }^{1}$, Joanne M. Fleming ${ }^{2}$, Primoz Gradisek ${ }^{7,8}$, \\ Rafael Kaps ${ }^{9}$, Theodoros Kyprianou ${ }^{10,11}$, Silvia Lagomarsino ${ }^{6}$, Isaac Lazar ${ }^{12}$, Costanza Martino ${ }^{13}$, \\ Malgorzata Mikaszewska-Sokolewicz ${ }^{14}$, Andrea Montis ${ }^{15}$, Gabor Nardai ${ }^{16}$, Giovanni Nattino ${ }^{2^{*}}$ (D), \\ Giuseppe Nattino ${ }^{17}$, Giulia Paci ${ }^{2}$, Laila Portolani ${ }^{13}$, Nektaria Xirouchaki ${ }^{18}$, Arturo Chieregato ${ }^{19}$ and \\ Guido Bertolini² for The CREACTIVE consortium
}

\begin{abstract}
Background: We leveraged the data of the international CREACTIVE consortium to investigate whether the outcome of traumatic brain injury (TBI) patients admitted to intensive care units (ICU) in hospitals without on-site neurosurgical capabilities (no-NSH) would differ had the same patients been admitted to ICUs in hospitals with neurosurgical capabilities (NSH).

Methods: The CREACTIVE observational study enrolled more than 8000 patients from 83 ICUs. Adult TBI patients admitted to no-NSH ICUs within $48 \mathrm{~h}$ of trauma were propensity-score matched 1:3 with patients admitted to NSH ICUs. The primary outcome was the 6-month extended Glasgow Outcome Scale (GOS-E), while secondary outcomes were ICU and hospital mortality.

Results: A total of 232 patients, less than $5 \%$ of the eligible cohort, were admitted to no-NSH ICUs. Each of them was matched to 3 NSH patients, leading to a study sample of 928 TBI patients where the no-NSH and NSH groups were well-balanced with respect to all of the variables included into the propensity score. Patients admitted to no-NSH ICUs experienced significantly higher ICU and in-hospital mortality. Compared to the matched NSH ICU admissions, their 6-month GOS-E scores showed a significantly higher prevalence of upper good recovery for cases with mild TBI and low expected mortality risk at admission, along with a progressively higher incidence of poor outcomes with increased TBI severity and mortality risk.
\end{abstract}

${ }^{\dagger}$ Aimone Giugni and Lorenzo Gamberini are shared first authorship.

The CREACTIVE consortium: The complete list of coauthors is provided in the Acknowledgments.

*Correspondence: giovanni.nattino@marionegri.it

${ }^{2}$ Laboratory of Clinical Epidemiology, Department of Public Health, Istituto Di Ricerche Farmacologiche Mario Negri IRCCS, Villa Camozzi, Via G.B. Camozzi 3, 24020 Ranica, Bergamo, Italy

Full list of author information is available at the end of the article

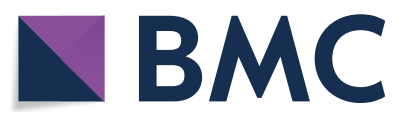

(c) The Author(s) 2021, corrected publication 2022. Open Access This article is licensed under a Creative Commons Attribution 4.0 International License, which permits use, sharing, adaptation, distribution and reproduction in any medium or format, as long as you give appropriate credit to the original author(s) and the source, provide a link to the Creative Commons licence, and indicate if changes were made. The images or other third party material in this article are included in the article's Creative Commons licence, unless indicated otherwise in a credit line to the material. If material is not included in the article's Creative Commons licence and your intended use is not permitted by statutory regulation or exceeds the permitted use, you will need to obtain permission directly from the copyright holder. To view a copy of this licence, visit http://creativecommons.org/licenses/by/4.0/. The Creative Commons Public Domain Dedication waiver (http://creativecommons.org/publicdomain/zero/1.0/) applies to the data made available in this article, unless otherwise stated in a credit line to the data. 
Conclusions: In our study, centralization of TBI patients significantly impacted short- and long-term outcomes. For TBI patients admitted to no-NSH centers, our results suggest that the least critically ill can effectively be managed in centers without neurosurgical capabilities. Conversely, the most complex patients would benefit from being treated in high-volume, neuro-oriented ICUs.

Keywords: Brain injuries, Traumatic, Outcome assessment, GOS-E, Prospective studies, Rehabilitation

\section{Background}

Traumatic brain injury (TBI) is an important medical, public health, and social problem worldwide [1-4] and is increasingly recognized as a global health priority. Globally, in 2016, TBI caused 8.1 million years of life lived with disabilities [5].

A considerable subset of TBI patients fails to return to baseline functional status at or beyond 3 months postinjury [6]. In some patients, further improvement is seen even as late as 5 years after injury. Evaluation of shortterm outcomes, as hospital mortality, runs the risk of only partially revealing the problems related to the sequelae of TBI. For this reason, it is essential to explore the disability phenomenon at least 6 months after injury [7].

Effective public health response to TBI requires programs devised to minimize adverse outcomes among the injured, including efforts to improve acute care and early management, and strategies to ensure patient access to appropriate care and services [8].

European networks for severe trauma patient care are mainly designed according to the hub-and-spoke model. Although a uniform standard of care for trauma center (TC) levels have not yet been defined across Europe, in general, level I TCs are highly specialized hospitals, level II TCs are regional hospitals with intermediate facilities, and level III TCs are local hospitals with low expertise in trauma care. The hub-and-spoke model involves all healthcare facilities operating in a region according to their expertise and resources, establishing the criteria for centralizing patients. A strict balance between the patient's needs and the level of care available in the receiving facility is fundamental to ensure the optimal functioning of such inclusive systems. Previous studies have found improved prognosis of the patients in mature, inclusive trauma systems $[9,10]$.

In addition to the general organ function support related to extra-cranial lesions, TBI patients admitted to ICUs could require neurosurgical interventions and specific expertise in neurocritical care. Therefore, these patients are usually directly admitted from the field or transferred early to hospitals with neurosurgical capabilities (NSH). On the other hand, since neurosurgical procedures, such as craniotomy or invasive intracranial pressure monitoring, are performed in less than $5 \%$ of TBI patients [11], other characteristics of NSH are expected to benefit TBI patients, as the greater intensity of neuro-oriented critical care [12], adherence to treatment guidelines [13], admission to high-volume centers [14] and an early, personalized, rehabilitation approach [15].

Nonetheless, a recent Italian study reported that about $12 \%$ of all severe TBI patients were admitted to the nearest hospital without neurosurgery capabilities (no-NSH) [16].

Various aspects could affect the decision to centralize TBI patients to NSH, as coma depth, pupil abnormalities, and severity of lesions in other districts. Moreover, it is not clear from the literature whether all strata of TBI severity requiring intensive care for either cranial or extra-cranial lesions effectively benefit from centralization to NSH.

This study aimed at evaluating whether centralization to NSH ICUs could have a role in the short- and longterm functional outcomes of these patients, as measured by the 6-month Glasgow Outcome Scale Extended (GOS-E) [17].

Data were extracted from the database of the CREACTIVE (Collaborative Research on Acute Traumatic Brain Injury in Intensive Care Medicine in Europe) consortium. CREACTIVE is an international prospective observational study aimed at describing the epidemiology of TBI in Europe and improving the quality of care in the field (ClinicalTrials.gov identifier: NCT02004080).

\section{Methods \\ Study cohort}

The CREACTIVE consortium was funded by the European Seventh Framework Programme for Research and Technological Development and involved 7 countries: Cyprus, Greece, Hungary, Israel, Italy, Poland, and Slovenia [18]. All TBI patients admitted to one of the participating ICUs were eligible for the study. More than 8000 patients from 83 ICUs were enrolled over 5 years, starting in March 2014.

To address the research question, we considered the adult patients of the CREACTIVE cohort and selected those admitted to the ICU no later than two days after the trauma. We did not exclude patients subject to secondary transfers. 
To address the lack of a uniform classification of TCs across 7 different countries, with different trauma system programming rules [19], we categorized the participating ICUs as NSH and no-NSH centers, depending on the inhospital availability of neurosurgery facilities.

Data on structural and organizational characteristics of the hospitals were collected through an ad-hoc web form. Patients' characteristics were collected using an electronic case report form (eCRF), including demographics, trauma characteristics, clinical conditions at emergency rescue team arrival and at admission to the emergency department and ICU, comorbidities, details of computed tomography (CT) scans in the first hours after trauma, and outcomes. The eCRF was built upon the existing PROSAFE framework, implementing several completeness and validy checks to guarantee the uniformity of the collected data [20].

The full lists of comorbidities and injuries considered in the data collection are provided in Additional file 1: Tables S1 and S2. In particular, to minimize the efforts required by the data collection, the eCRF only included traumatic lesions characterized by an Abbreviated Injury Scale (AIS) severity greater than 2 .

The Ethics Committee Lazio 1 of the Azienda Ospedaliera San Camillo Forlanini, Rome, Italy, and the local ethics committees at the participating centers approved the study protocol. Written informed consent was obtained from patients or their legal representatives. Where national legislation so permitted and considering the study's observational nature, a waived or delayed consent process was implemented in patients in coma or experiencing high-stress levels.

\section{Outcome}

The primary outcome of the study was the six-month GOS-E, the most widely used scale to evaluate disability in TBI patients. GOS-E is divided into 8 levels: death, vegetative state, severe disability (lower and upper), moderate disability (lower and upper), and good recovery (lower and upper), and was assessed by telephone interview. The ICU nurses made the calls; they were trained in a dedicated two-day course and were blinded to the aim of this study. The secondary outcomes of the study were ICU and hospital mortality.

\section{Statistical analysis}

The results are presented following the research reporting guidelines of the Strengthening the Reporting of Observational Studies in Epidemiology (STROBE) statement [21]. Mean and standard deviation or median and interquartile range were used to describe quantitative variables. Binary and categorical variables were described by counts and proportions.
We used a propensity-score-matched design to address the research question. The propensity score is the probability of being exposed to a treatment of interest given pre-treatment variables [22]. Under a set of technical assumptions, this methodology can estimate causal effects in observational studies by attempting to create, a posteriori, the balanced design resulting from a randomized trial [23]. The propensity score was estimated by logistic regression, with the binary variable indicating whether the patient was admitted to a no-NSH center being the response. The variables included in the model were identified by a panel of clinicians involved in the study (ArC, AG, EF, LG, VB) as the set of variables related to both admission to an NSH center and patient outcome, as suggested by the literature [23]. No-NSH patients were 1:3 matched to NSH patients on the propensity score through the two-group optimal matching algorithm $[24,25]$. The goal was to identify NSH patients similar to no-NSH ones with respect to all of the propensity-score variables, which included several demographics, characteristics of the trauma and clinical conditions (the list is provided in Additional file 1: Table S3). The panel of clinicians considered particularly important the balance of pupillary response at the emergency department (ED), pre-ICU hypotension, and age. Thus, we forced the algorithm to match exactly on the first two factors and to match no-NSH patients to NSH patients differing at most by 5 years of age.

The matching quality was evaluated in terms of propensity score balance, using standardized mean differences [23]. Differences smaller than 0.1 are commonly considered negligible. In well-balanced matched samples, outcome analyses may proceed with unadjusted comparisons. We compared the proportion of subjects in the outcome groups with risk differences (with 95\% confidence intervals $[\mathrm{CI}]$ ) and performed chi-squared tests. Statistical software R, version 3.6.1, was used for the analyses.

\section{Results}

Figure 1 illustrates the flow of patients through the study. Of the 8179 CREACTIVE cohort patients, 7558 (92.2\%) were adults. After excluding patients admitted to the ICU later than 2 days post-trauma and those with missing information, the cohort was formed by 6914 (91.4\%) patients eligible for matching; of them, only 232 (3.4\%) were admitted to ICUs in no-NSH hospitals. Additional file 1: Table S4 describes the countries where the participating ICUs were located and the structural/organizational characteristics of the ICUs belonging to the NSH, matched NSH, and no-NSH groups; Additional file 1: Figure $\mathrm{S} 1$ shows the number of subjects for each participating center. 


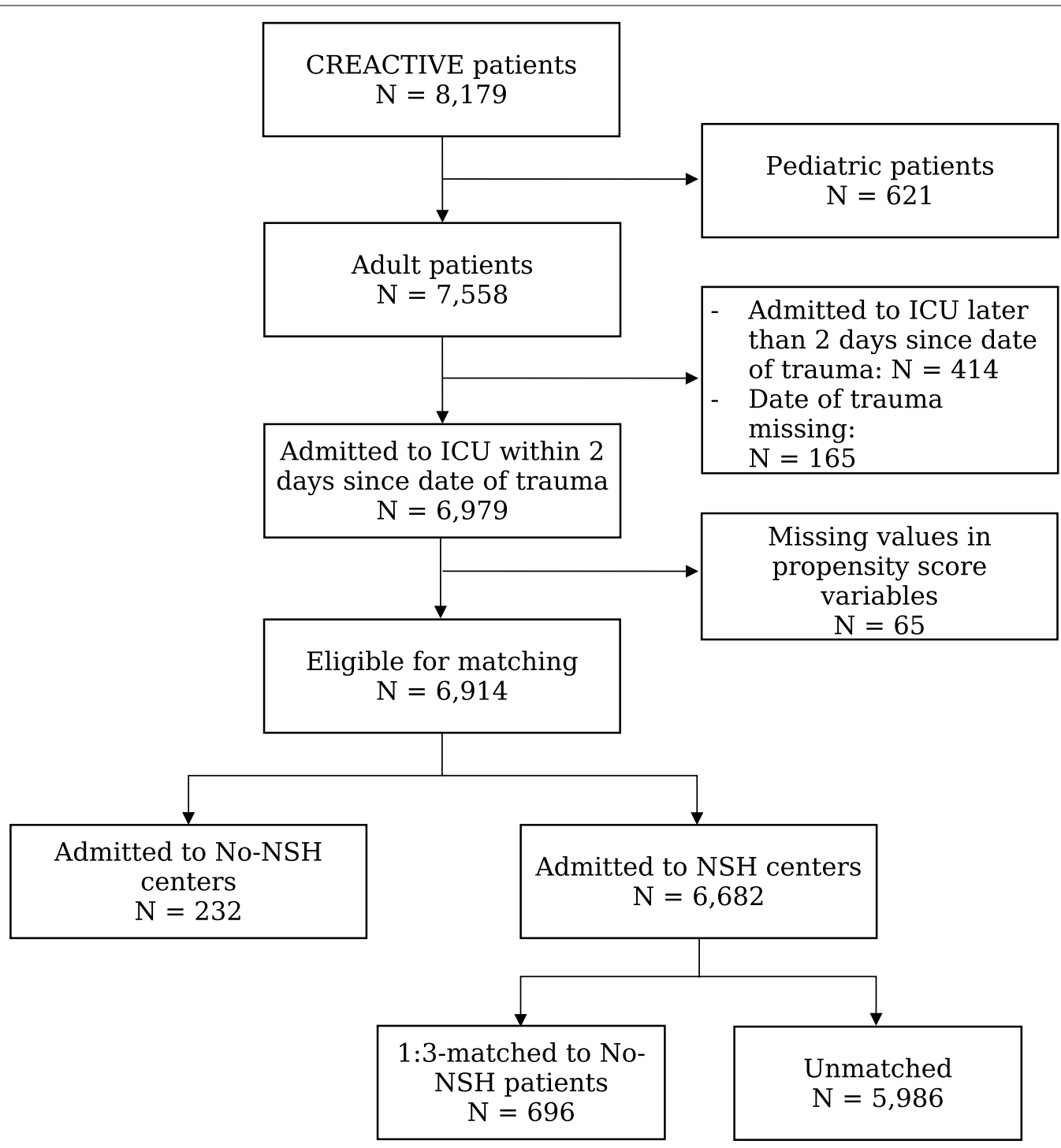

Fig. 1 Flow-chart describing the patient selection

The matched sample included a total of 67 ICUs: 14 no-NSH and $53 \mathrm{NSH}$. The no-NSH ICUs belonged to smaller hospitals (with a median of 333 vs. 664 beds), had a lower number of ICU beds ( 6 vs. 10), and managed a lower yearly number of both general trauma (28 vs. 77.9 patients/year) and TBI patients (9.8 vs. 47.6 patients/ year).

A total of 24 variables were included in the propensity score model. The complete list of variables and the corresponding odds ratio estimates are provided in Additional file 1: Table S3. Following 1:3 propensity score-based matching, the final cohort included 928 patients: 232 admitted to the no-NSH ICUs and 696 matched from the NSH cohort.
Table 1 compares the demographic and clinical characteristics of the patients admitted to NSH and no-NSH ICUs before and after matching. Globally, compared to the cases admitted to no-NSH ICUs, the NSH cohort exhibited a lower prevalence of low-energy impacts and patients aged over 65, more severe derangements in terms of vital parameters both in the ED and at ICU admission, and worse Marshall grades at head CT scans.

The standardized means of the variables included in the propensity score before and after matching are provided in Additional file 1: Table S5, while Additional file 1: Figure S2 shows the relative distribution of the propensity score before and after matching. Since all standardized means were less or equal to 0.1 after matching, the 
Table 1 Demographic and clinical characteristics of the enrolled patients

\begin{tabular}{|c|c|c|c|c|}
\hline \multirow[t]{2}{*}{ Variables } & \multicolumn{2}{|l|}{ NSH } & \multirow[t]{2}{*}{ No NSH } & \multirow[t]{2}{*}{$P$ value $^{\mathrm{a}}$} \\
\hline & All & Matched (1:3) & & \\
\hline N & 6682 & 696 & 232 & \\
\hline Age & & & & 0.959 \\
\hline Mean (SD) & $55.0(21.0)$ & $64.5(20.1)$ & $64.6(20.3)$ & \\
\hline Median (Q1-Q3) & $57.0(38.0-74.0)$ & $71.0(51.0-80.0)$ & $73.0(51.8-80.0)$ & \\
\hline Sex (female)—N (\%) & $1775(26.6)$ & $213(30.6)$ & $71(30.6)$ & 1.000 \\
\hline Occupational status—N (\%) & & & & 0.013 \\
\hline Worker & $1633(28.6)$ & $120(20.5)$ & $38(21.2)$ & \\
\hline Retired & $1594(28.0)$ & $265(45.2)$ & $102(57.0)$ & \\
\hline Unemployed & $247(4.3)$ & $16(2.7)$ & $6(3.4)$ & \\
\hline Student & $275(4.8)$ & $10(1.7)$ & $4(2.2)$ & \\
\hline Disabled/Sheltered employment & $104(1.8)$ & $11(1.9)$ & $3(1.7)$ & \\
\hline Unknown & $1849(32.4)$ & $164(28.0)$ & $26(14.5)$ & \\
\hline Missing ${ }^{b}$ & 980 & 110 & 53 & \\
\hline Marital status-N (\%) & & & & 0.055 \\
\hline Unmarried/single & $1204(21.1)$ & $79(13.5)$ & $21(11.7)$ & \\
\hline Married & $2033(35.6)$ & $225(38.4)$ & $88(49.2)$ & \\
\hline Separated/divorced & $172(3.0)$ & $16(2.7)$ & $8(4.5)$ & \\
\hline Widowed & $399(7.0)$ & $69(11.8)$ & $17(9.5)$ & \\
\hline Unknown & $1896(33.2)$ & $197(33.6)$ & $45(25.1)$ & \\
\hline Missing ${ }^{b}$ & 978 & 110 & 53 & \\
\hline Education level—N (\%) & & & & 0.015 \\
\hline No schooling & $117(2.1)$ & $13(2.2)$ & $4(2.2)$ & \\
\hline Primary school/elementary school & $1230(21.6)$ & $133(22.7)$ & $63(35.2)$ & \\
\hline High school diploma & $1043(18.3)$ & $81(13.8)$ & $19(10.6)$ & \\
\hline University degree or higher & $243(4.3)$ & $16(2.7)$ & $2(1.1)$ & \\
\hline Unknown & $3071(53.8)$ & $343(58.5)$ & $91(50.8)$ & \\
\hline Missing ${ }^{b}$ & 978 & 110 & 53 & \\
\hline \multicolumn{5}{|l|}{ Comorbidities—N (\%) } \\
\hline Any comorbidity ${ }^{c}$ & $3506(52.5)$ & $458(65.8)$ & $154(66.4)$ & 0.873 \\
\hline Antiplatelet therapy & $517(7.7)$ & $63(9.1)$ & $20(8.6)$ & 0.842 \\
\hline Arrhythmia & $608(9.1)$ & $108(15.5)$ & $36(15.5)$ & 1.000 \\
\hline Cerebrovascular disease & $449(6.7)$ & $74(10.6)$ & $19(8.2)$ & 0.283 \\
\hline COPD & $262(3.9)$ & $37(5.3)$ & $14(6.0)$ & 0.678 \\
\hline Dementia & $180(2.7)$ & $14(2.0)$ & $7(3.0)$ & 0.372 \\
\hline Drug-induced coagulopathy & $370(5.5)$ & $67(9.6)$ & $20(8.6)$ & 0.649 \\
\hline Diabetes Type II & $706(10.6)$ & $81(11.6)$ & $26(11.2)$ & 0.859 \\
\hline Hypertension & $2083(31.2)$ & $316(45.4)$ & $102(44.0)$ & 0.703 \\
\hline Myocardial infarction & $358(5.4)$ & $49(7.0)$ & $25(10.8)$ & 0.069 \\
\hline Penetrating trauma $-\mathrm{N}(\%)$ & $210(3.1)$ & $16(2.3)$ & $4(1.7)$ & 0.602 \\
\hline Traffic accident-N (\%) & $3052(45.7)$ & $257(36.9)$ & $84(36.2)$ & 0.844 \\
\hline Trauma dynamic —N (\%) & & & & 0.493 \\
\hline High-energy impact & $2833(42.4)$ & $232(33.3)$ & $68(29.3)$ & \\
\hline Low-energy impact & $2418(36.2)$ & $330(47.4)$ & $119(51.3)$ & \\
\hline Other & $1430(21.4)$ & $134(19.3)$ & $45(19.4)$ & \\
\hline Missing & 1 & 0 & 0 & \\
\hline Pre-treatment GCS—N (\%) & & & & 0.382 \\
\hline Mean (SD) & $8.9(4.4)$ & $11.0(4.3)$ & $11.2(4.3)$ & \\
\hline Median (Q1-Q3) & $8(5-13)$ & $13(7-15)$ & $13(8-15)$ & \\
\hline
\end{tabular}


Table 1 (continued)

\begin{tabular}{|c|c|c|c|c|}
\hline \multirow[t]{2}{*}{ Variables } & \multicolumn{2}{|l|}{ NSH } & \multirow[t]{2}{*}{ No NSH } & \multirow[t]{2}{*}{$P$ value ${ }^{a}$} \\
\hline & All & Matched (1:3) & & \\
\hline $3-8$ & $3354(50.2)$ & $195(28.0)$ & $62(26.7)$ & \\
\hline $9-13$ & $1735(26.0)$ & $211(30.3)$ & $60(25.9)$ & \\
\hline $14-15$ & $1593(23.8)$ & $290(41.7)$ & $110(47.4)$ & \\
\hline \multicolumn{5}{|l|}{ Main lesion—N (\%) } \\
\hline Cerebral contusion/laceration & $1715(25.7)$ & $125(18.0)$ & $40(17.2)$ & 0.804 \\
\hline Extradural/epidural haematoma & $581(8.7)$ & $42(6.0)$ & $10(4.3)$ & 0.323 \\
\hline Traumatic subdural haematoma & $2216(33.2)$ & $161(23.1)$ & $59(25.4)$ & 0.476 \\
\hline Intraparenchymal bleeding & $554(8.3)$ & $138(19.8)$ & $47(20.3)$ & 0.887 \\
\hline Diffuse injury without oedema & $422(6.3)$ & $19(2.7)$ & $5(2.2)$ & 0.633 \\
\hline Diffuse injury with oedema & $301(4.5)$ & $18(2.6)$ & $5(2.2)$ & 0.715 \\
\hline Subarachnoid haemorrhage & $755(11.3)$ & $171(24.6)$ & $60(25.9)$ & 0.693 \\
\hline Skull fracture & $138(2.1)$ & $22(3.2)$ & $6(2.6)$ & 0.658 \\
\hline \multicolumn{5}{|l|}{ Injuries other than TBId—N (\%) } \\
\hline Isolate TB| & $3595(53.8)$ & $398(57.2)$ & $123(53.0)$ & 0.268 \\
\hline Abdomen & $652(9.8)$ & $35(5.0)$ & $10(4.3)$ & 0.659 \\
\hline Chest & $2089(31.3)$ & $193(27.7)$ & $73(31.5)$ & 0.276 \\
\hline Pelvis, bones, joints and muscles & $1458(21.8)$ & $154(22.1)$ & $42(18.1)$ & 0.194 \\
\hline Major vessels & $176(2.6)$ & $14(2.0)$ & $1(0.4)$ & 0.134 \\
\hline Spine & $1363(20.4)$ & $135(19.4)$ & $46(19.8)$ & 0.886 \\
\hline Other & $17(0.3)$ & $2(0.3)$ & $0(0.0)$ & 1.000 \\
\hline Time between injury and ICU adm. (hours) & & & & 0.085 \\
\hline Mean (SD) & $8.3(10.2)$ & $9.1(12.0)$ & $7.6(9.3)$ & \\
\hline Median (Q1-Q3) & $4.8(2.9-8.5)$ & $4.5(2.7-9.0)$ & $5.0(2.8-7.4)$ & \\
\hline Missing & 1232 & 119 & 17 & \\
\hline Pupils at ED arrival—N (\%) & & & & 0.985 \\
\hline Bilaterally reactive/miotic & $4776(71.5)$ & $583(83.8)$ & $195(84.1)$ & \\
\hline Unilaterally dilated/non-reactive & $1044(15.6)$ & $54(7.8)$ & $19(8.2)$ & \\
\hline Bilaterally dilated/non-reactive & $637(9.5)$ & $36(5.2)$ & $11(3.0)$ & \\
\hline Not available & $225(3.4)$ & $23(3.3)$ & $7(3.0)$ & \\
\hline Hypotension-N (\%) & $990(14.8)$ & $57(8.2)$ & $19(8.2)$ & 1.000 \\
\hline Hypoxia-N (\%) & $1587(23.8)$ & $74(10.6)$ & $24(10.3)$ & 0.902 \\
\hline $\begin{array}{l}\text { Haemorrhagic-hypovolemic shock on ICU admis- } \\
\text { sion—N (\%) }\end{array}$ & $702(10.5)$ & $31(4.5)$ & $10(4.3)$ & 0.927 \\
\hline Neurogenic shock on ICU admission-N (\%) & $523(7.8)$ & $27(3.9)$ & $10(4.3)$ & 0.771 \\
\hline SAPS II (worst $24 \mathrm{~h}$ from ICU admission) & & & & 0.877 \\
\hline$<41$ [probability: 0.00-0.25] & $2085(46.3)$ & $330(56.7)$ & $120(57.4)$ & \\
\hline 41-51 [probability:0.26-0.50] & $925(20.6)$ & $89(15.3)$ & $31(14.8)$ & \\
\hline 52-63 [probability: 0.51-0.75] & $808(18.0)$ & $97(16.7)$ & $38(18.2)$ & \\
\hline$>63$ [probability: 0.76-1.00] & $682(15.2)$ & $66(11.3)$ & $20(9.6)$ & \\
\hline SAPSII not assessable & 2182 & 114 & 23 & \\
\hline \multicolumn{5}{|l|}{ Worst CT scan of first $48 \mathrm{~h}$ in ICU—N (\%) } \\
\hline Marshall scale & & & & 0.943 \\
\hline Diffuse Injury I & $730(10.9)$ & $159(22.8)$ & $55(23.7)$ & \\
\hline Diffuse Injury II & $2339(35.0)$ & $291(41.8)$ & $91(39.2)$ & \\
\hline Diffuse Injury III & $631(9.4)$ & $42(6.0)$ & $13(5.6)$ & \\
\hline Diffuse Injury IV & $229(3.4)$ & $34(4.9)$ & $11(4.7)$ & \\
\hline Mass lesion (V or VI) & $2753(41.2)$ & $170(24.4)$ & $62(26.7)$ & \\
\hline Midline shift > 5 mm & $2150(32.2)$ & $139(20.0)$ & $51(22.0)$ & 0.511 \\
\hline
\end{tabular}


Table 1 (continued)

\begin{tabular}{|c|c|c|c|c|}
\hline \multirow[t]{2}{*}{ Variables } & \multicolumn{2}{|l|}{ NSH } & \multirow[t]{2}{*}{ No NSH } & \multirow[t]{2}{*}{$P$ value } \\
\hline & All & Matched (1:3) & & \\
\hline Lesion volume $>25 \mathrm{ml}$ & $2217(33.2)$ & $148(21.3)$ & $54(23.3)$ & 0.520 \\
\hline Petechiae & $2419(36.2)$ & $180(25.9)$ & $59(25.4)$ & 0.897 \\
\hline Cistern condition & & & & 0.622 \\
\hline Normal & $3046(45.6)$ & $339(48.7)$ & $105(45.3)$ & \\
\hline Compressed or distorted & $2541(38.0)$ & $182(26.1)$ & $67(28.9)$ & \\
\hline Absent & 1095 (16.4) & $175(25.1)$ & $60(25.9)$ & \\
\hline
\end{tabular}

a $P$ value comparing no-NSH and matched NSH patients

${ }^{b}$ The information is not available for patients enrolled in 2014

'The complete list of comorbidities is reported in the Additional file 1: Table S1

${ }^{d}$ The complete list of lesions considered in each body region is reported in the Additional file 1: Table S2

no-NSH and NSH groups were considered well-balanced for all of the variables of interest.

Figure 2 depicts the distribution of matched patients' cohorts among the predicted mortality strata, based on Simplified Acute Physiology score II (SAPS II) values at ICU admission,neurological status based on pre-treatment Glasgow Coma Scale (GCS) score and Marshall classification of the worst CT scan in the first $48 \mathrm{~h}$ in the ICU. Of note, pre-treatment GCS and Marshall classification were available for all patients while SAPS II score was unassessable at ICU admission for 137 out of 928 patients (14.8\% of cases) due to deep sedation and failure to reliably estimate GCS within the first $24 \mathrm{~h}$ after ICU admission.

Clinical severity at ICU admission in the matched populations showed bimodal distribution. About half of the cases had SAPS II score below 40, corresponding to a predicted mortality lower than $25 \%$, while a second peak was observed for SAPS II ranging from 52 to 63 , with related expected mortality between 50 and $75 \%$. As regards GCS evaluation pre-treatment, most patients fell in the range of mild TBI (GCS $13-15,53.1 \%$ vs. $56.5 \%$, respectively for NSH ICUs and no-NSH ICUs), while the second most represented group was classifiable as severe TBI (GCS $3-8,28.0 \%$ vs. $26.8 \%$ ). A similar bimodal pattern was observed for the Marshall CT classification. Further details can be found in Table 1.

Table 2 shows the outcome-related variables. Specifically, ICU and hospital mortality were significantly higher in the no-NSH group, with similar lengths of ICU and hospital stays. After ICU discharge, a slightly higher percentage of patients were directly transferred to rehabilitation wards in the NSH group.

Patients admitted to NSH ICUs experienced a significantly higher number of respiratory ( $12.9 \%$ vs. $5.2 \%)$ and infectious $(27.7 \%$ vs. $19.0 \%)$ complications during ICU stay. In contrast, major neurological complications (intracranial hypertension $>20 \mathrm{mmHg}$, refractory intracranial hypertension, one or more episodes of dilated pupils unreactive to light, and brain edema) were more frequently observed in the no-NSH group $(31.9 \%$ vs. $25.7 \%)$, but without significant difference $(p=0.067)$. When intracranial pressure was not invasively monitored, the diagnosis of intracranial hypertension was based on the CT scan, in the presence of clearly specified signs (reduced or absent cisterns, compressed third or lateral ventricles, evidence of a midline shift in the presence of subfalcine and transtentorial herniation). Nurosurgical interventions performed in NSH centers are provided in Additional file 1: Table S6.

Comparison of GOS-E scores at 6 months post-trauma yielded a significantly different distribution of functional outcomes between the two groups. Patients discharged from no-NSH ICUs more frequently reported good recovery than those discharged from NSH ICUs, while moderate and severe disability were more commonly observed in NSH ICUs. To better explore this finding, the same outcomes were evaluated by stratifying both patient cohorts into severity classes.

Figure 3 shows the distribution of the 6-month GOS-E stratified for predicted mortality at ICU admission, according to SAPS II score, TBI categories based on pretreatment GCS and the Marshall CT classification. In the stratum with the lowest risk of death according to SAPS II, a higher proportion of good recovery was observed for patients admitted to no-NSH ICUs. The mortality gap between the two groups was at its widest for predicted mortality of $25-50 \%$, with lower mortality in NSH hospitals. The mortality gap narrowed in the group with a $50-75 \%$ risk of death, almost disappearing in the highestrisk stratum.

Regarding the TBI and Marshall classification, at 6-month GOS-E, patients treated in no-NSH ICUs showed lower mortality and a higher prevalence of good 
(a) SAPSII

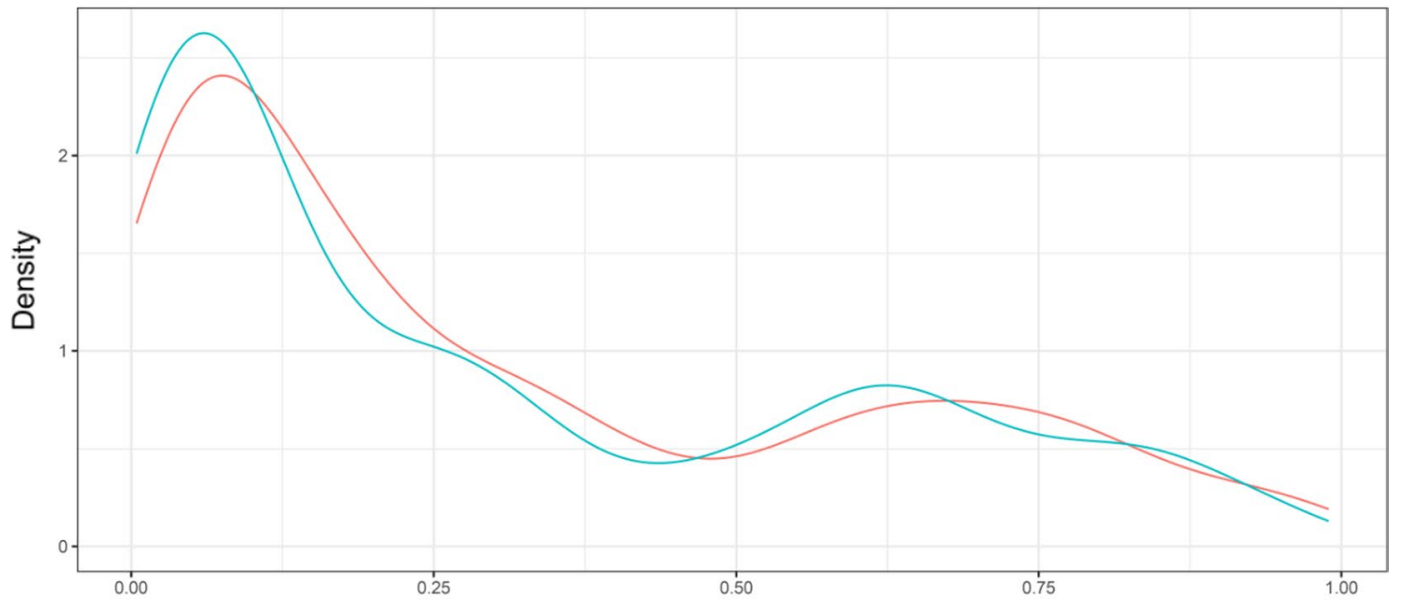

(b) GCS

Probability of hospital mortality based on SAPSII

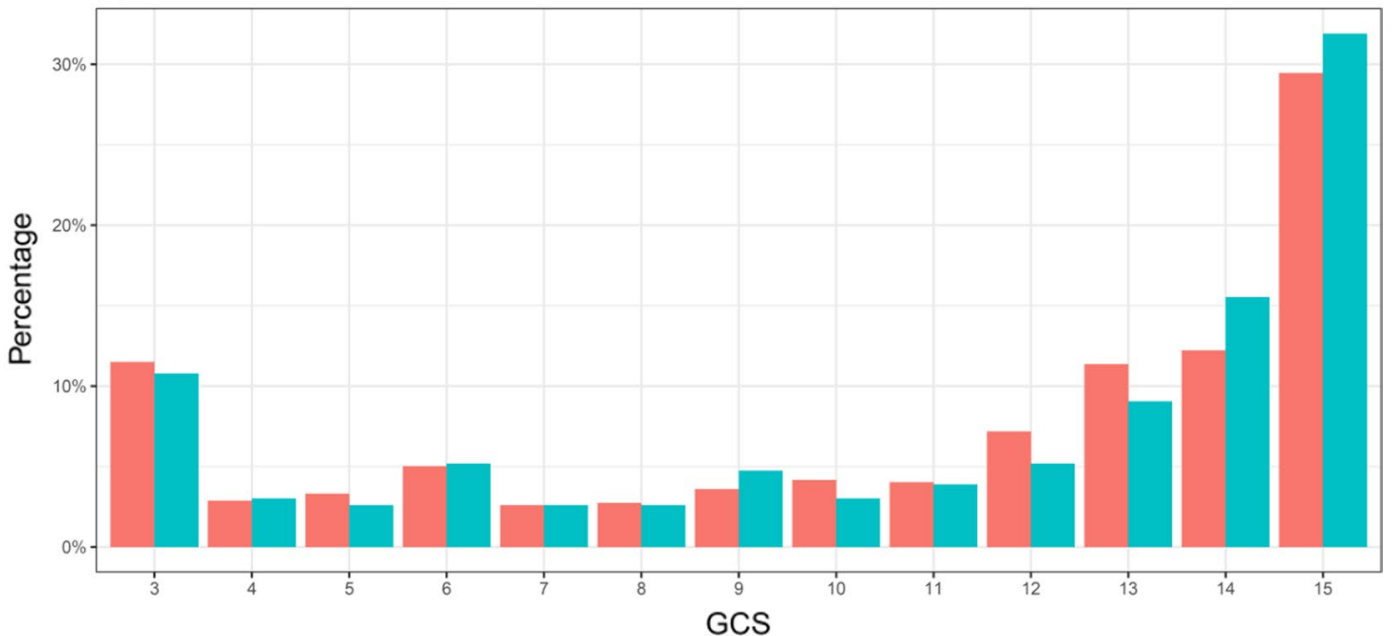

(c) Marshall

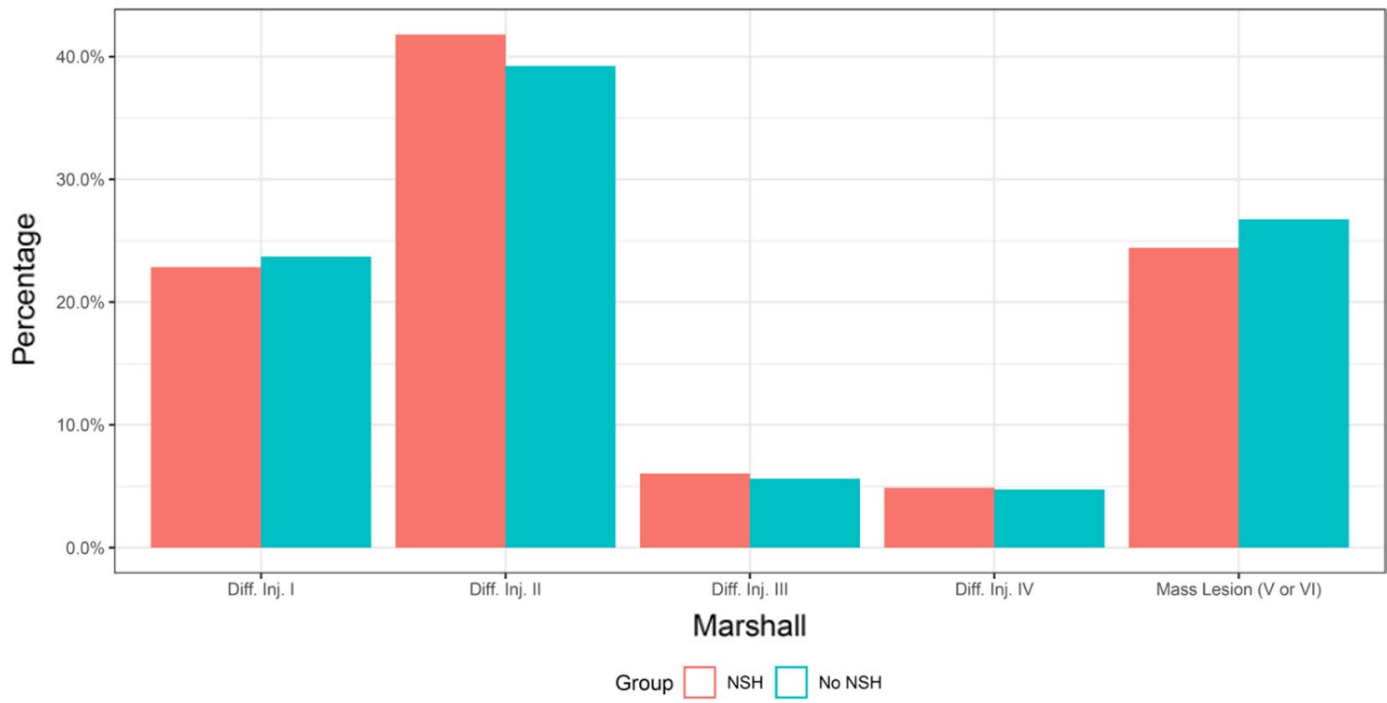

Fig. 2 Distributions of the probability of hospital mortality as calculated by the SAPSII score (top panel), GCS before any treatment (central panel) and Marshall classification (bottom panel) in the NSH and no-NSH groups of the matched sample 
Table 2 Interventions and outcomes of the study cohort

\begin{tabular}{|c|c|c|c|c|}
\hline \multirow[t]{2}{*}{ Variables } & \multicolumn{2}{|l|}{ NSH } & \multirow[t]{2}{*}{ No NSH } & \multirow[t]{2}{*}{$P$ value $^{\mathrm{a}}$} \\
\hline & All & Matched (1:3) & & \\
\hline \multicolumn{5}{|l|}{ Interventions in ICUs-N (\%) } \\
\hline Hypothermia & $93(1.4)$ & $5(0.7)$ & $1(0.4)$ & 0.636 \\
\hline External ventricular drainage without ICP monitoring & $92(1.4)$ & $2(0.3)$ & $1(0.4)$ & 0.738 \\
\hline External ventricular drainage with ICP monitoring ${ }^{b}$ & $398(6.0)$ & $31(4.5)$ & $0(0.0)$ & 0.001 \\
\hline Barbiturate infusion for refractory ICP & $393(5.9)$ & $18(2.6)$ & $1(0.4)$ & 0.045 \\
\hline Hyperventilation $\mathrm{paCO} 2<25 \mathrm{mmHg}$ & $312(4.7)$ & $17(2.4)$ & $9(3.9)$ & 0.251 \\
\hline Indomethacin & $23(0.3)$ & $0(0.0)$ & $0(0.0)$ & 1.000 \\
\hline Mannitol (multiple doses) & $1613(24.1)$ & $119(17.1)$ & $43(18.5)$ & 0.618 \\
\hline Hypertonic saline & $816(12.2)$ & $46(6.6)$ & $15(6.5)$ & 0.939 \\
\hline Invasive monitoring of intracranial pressure ${ }^{c}$ & $1930(28.9)$ & $105(15.1)$ & $6(2.6)$ & $<0.001$ \\
\hline \multicolumn{5}{|l|}{ Complications during ICU stay —N (\%) } \\
\hline Cardiovascular & $693(10.4)$ & $59(8.5)$ & $14(6.0)$ & 0.231 \\
\hline Gastrointestinal & $197(2.9)$ & $17(2.4)$ & $3(1.3)$ & 0.296 \\
\hline Neurological $^{d}$ & $2438(36.5)$ & $179(25.7)$ & $74(31.9)$ & 0.067 \\
\hline Respiratory & $954(14.3)$ & $90(12.9)$ & $12(5.2)$ & 0.001 \\
\hline Other & $325(4.9)$ & $24(3.4)$ & $3(1.3)$ & 0.091 \\
\hline Infections & $2423(36.3)$ & $193(27.7)$ & $44(19.0)$ & 0.008 \\
\hline Missing & 2 & 0 & 0 & \\
\hline Three-day mortality — N deaths (\%) & $836(12.5)$ & $66(9.5)$ & $18(7.8)$ & 0.428 \\
\hline Missing & 2 & 0 & 0 & \\
\hline \multicolumn{5}{|l|}{ ICU outcome } \\
\hline Dead—N (\%) & $1569(23.5)$ & $143(20.5)$ & $67(28.9)$ & 0.009 \\
\hline Missing vital status & 7 & 0 & 0 & \\
\hline If alive, conditions at discharge: & & & & 0.674 \\
\hline Follow simple commands—N (\% on alive) & $1443(28.5)$ & $116(21.3)$ & $32(19.8)$ & \\
\hline Cannot follow simple commands_-N (\% on alive) & $3607(71.5)$ & $429(78.7)$ & $130(80.2)$ & \\
\hline Missing conditions at discharge & 63 & 8 & 3 & \\
\hline If alive, discharged to: & & & & $<0.001$ \\
\hline Ward-N (\% on alive) & $2283(44.7)$ & $282(51.0)$ & $115(69.7)$ & \\
\hline Other ICU—N (\% on alive) & $1167(22.9)$ & $113(20.4)$ & $26(15.8)$ & \\
\hline High dependency unit—N (\% on alive) & $1276(25.0)$ & $137(24.8)$ & $16(9.7)$ & \\
\hline Rehabilitation—N (\% on alive) & $358(7.0)$ & $20(3.6)$ & $2(1.2)$ & \\
\hline Day hospital or long-term care-N (\% on alive) & $5(0.1)$ & $1(0.2)$ & $5(3.0)$ & \\
\hline Home $-\mathrm{N}$ (\% on alive) & $17(0.3)$ & $0(0.0)$ & $1(0.6)$ & \\
\hline Hospital mortality—N deaths (\%) & $2054(30.9)$ & $194(28.0)$ & $82(35.5)$ & 0.030 \\
\hline Missing & 41 & 2 & 1 & \\
\hline \multicolumn{5}{|l|}{ ICU stay (days)—Median (Q1-Q3) } \\
\hline Alive after ICU & $9.0(3.0-18.0)$ & $5.0(2.0-13.0)$ & $4.0(2.0-12.0)$ & 0.872 \\
\hline Deaths in ICU & $3.0(1.0-7.0)$ & $3.0(1.0-7.0)$ & $5.0(2.0-10.0)$ & 0.049 \\
\hline Missing & 2 & 1 & 0 & \\
\hline \multicolumn{5}{|l|}{ Hospital stay (days) —Median (Q1-Q3) } \\
\hline Alive after ICU & $19.0(10.0-34.0)$ & $16.0(9.0-.0)$ & $14.0(7.0-25.0)$ & 0.130 \\
\hline Missing & 17 & 0 & 0 & \\
\hline 6-month GOS-E-N (\%) & & & & 0.010 \\
\hline Severe disability pre-TBI & $86(1.6)$ & $17(3.2)$ & $4(2.1)$ & \\
\hline Moderate disability pre-TBI & $53(1.0)$ & $4(0.7)$ & $0(0.0)$ & \\
\hline Dead (1) & $2308(42.6)$ & $228(42.3)$ & $87(46.5)$ & \\
\hline Vegetative State (2) & $174(3.2)$ & $12(2.2)$ & $4(2.1)$ & \\
\hline
\end{tabular}


Table 2 (continued)

\begin{tabular}{llll}
\hline Variables & NSH & & No NSH \\
\cline { 2 - 3 } & All & Matched (1:3) & \\
\hline Lower severe disability (3) & $748(13.8)$ & $76(14.1)$ & $20(10.7)$ \\
Upper severe disability (4) & $407(7.5)$ & $43(8.0)$ & $11(5.9)$ \\
Lower moderate disability (5) & $267(4.9)$ & $21(3.9)$ & $2(1.1)$ \\
Upper moderate disability (6) & $428(7.9)$ & $38(7.1)$ & $9(4.8)$ \\
Lower good recovery (7) & $427(7.9)$ & $44(8.2)$ & $10(5.3)$ \\
Upper good recovery (8) & $514(9.5)$ & $56(10.4)$ & $40(21.4)$ \\
Missing & 1270 & 157 & 45
\end{tabular}

a P-value comparing no-NSH and matched NSH patients

${ }^{\mathrm{b}}$ Intraventricular catheter for both intracranial pressure monitoring and drainage of cerebral spinal fluid

'Invasive monitoring of intracranial pressure includes subdural, subarachnoid, intraparenchymal, intraventricular probe insertion for the sole intracranial pressure monitoring

${ }^{d}$ Neurological complications include intracranial hypertension, episodes of dilated pupils unreactive to light and brain edema

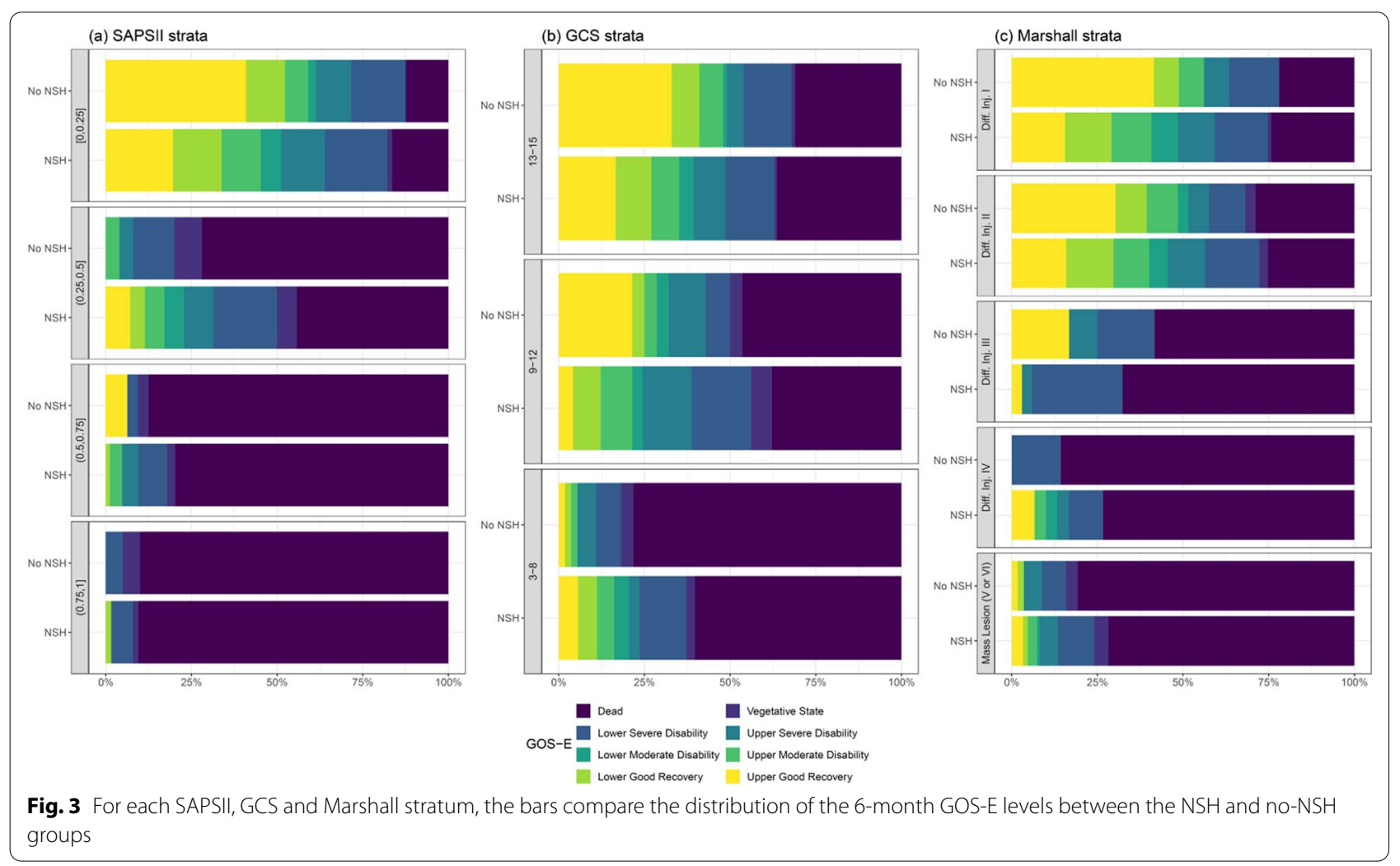

outcomes in the mild TBI and diffuse injury I groups. Conversely, in moderate and severe TBI patients, death and poor outcomes were significantly more frequent for no-NSH ICUs. Similarly, as the severity of the Marshall classification increased, we observed a progressively higher frequency of worse outcomes for no-NSH patients.
To assess whether our results could have been affected by patients considered in the no-NSH group and secondarily transferred and treated in NSH centers, we quantified the number of secondary transfers from no-NSH centers. Only 11 no-NSH patients (4.7\%) were transferred to another ICU for step-up care. Unfortunately, the availability of neurosurgery in the receiving hospital was not collected, nor we collected the information on whether 
the transfer was motivated by the presence of neurosurgery facilities or for other specialties of the higher-level hospitals. Nonetheless, secondary transfers from no NSH can impact our results only negligibly, as their number is bounded by the very limited number of step-up transfers.

\section{Discussion}

This study focused on TBI patients admitted to ICUs without neurosurgical capabilities, specifically evaluating if their 6-month functional recovery would have been different if these patients had been admitted to an NSH center instead.

Overall, only $3.3 \%$ of patients with TBI admitted to an ICU were primarily taken to a hospital without neurosurgery capabilities. The distribution of their severity, based on the SAPS II score, follows a bimodal pattern, yielding a larger cohort of patients with low expected mortality $(<25 \%)$ and a smaller group with high expected mortality (50-75\%). More than half of the patients were classified as mild TBI; the second most represented group was severe TBI. Older age, low energy impact, higher GCS at ICU admission, and fewer derangements in terms of oxygenation and hemodynamics were more frequent in patients admitted to no-NSH ICUs, as already reported in the literature [26, 27]. These factors, which have been discussed as potential causes of both improper centralization [28, 29] and in-hospital undertriage [30], could, together with distance to higher-level TCs from the trauma site [31] and time of day of the event (in particular for emergency medical helicopter services), have partially contributed to the bimodal distribution of the population with respect to severity score at ICU admission in noNSH (Fig. 2). Moreover, for the most severely injured patients, transportation to no-NSH centers could also reflect pre-hospital uncertainty about real survival benefits in relation to the transfer time to high-level TCs.

Notably, we found several patients admitted to NSH centers who were similar to those transported to no-NSH ICUs. This was what made the comparison between the two different settings possible, in terms of patients' outcomes. In this regard, it is essential to point out that we did not evaluate the centralization of TBI patients in general. Instead, we aimed at assessing what would have been the outcome of the TBI patients that were admitted to no-NSH centers had they have been centralized to NSH ones.

The six-month GOS-E distribution showed that patients with the lowest estimated mortality risk admitted to no-NSH ICUs had lower mortality and better functional recovery than similar patients admitted to NSH ICUs. As the risk of death increased, no-NSH ICUs showed higher mortality at 6 months and increasingly poor functional outcomes compared to NSH ICUs. Similarly, when stratifying the cohort by TBI severity, mild TBI patients showed better functional outcomes and lower mortality in no-NSH ICUs, while severe TBI patients showed better functional outcomes and lower mortality in NSH ICUs.

While the results on severe patients are in line with current literature [32,33], the findings on mild cases are somewhat new and warrant further discussion. Other studies reported better functional outcomes, adjusted for trauma severity scores, in higher-level TCs for the general trauma population [34]. These results are not in disagreement with our findings. While these studies focused on the population of all TBI patients, most of whom are admitted to highly specialized hospitals, our conclusions applies only to those patients (3\% of our study cohort) who were admitted to no-NSH centers. On the other hand, a recent study evaluating the TBI population [35] failed to find any effect of centralization to level I TCs in terms of 6-month GOS-E, in a cohort of TBI patients with a median age over 70 years.

One possible explanation for our results is that NSH centers deliver more aggressive and invasive neurooriented therapies (see Table 2), and are consequently more focused on these specific problems. On the other hand, no-NSH ICUs may pay greater attention to nonTBI-related clinical aspects, which they are used to manage. For mild TBI patients, these aspects presumably are the most important in determining the outcome. Both hypotheses seem supported by the significantly higher incidence of extra-neurologic complications in NSH centers and the lower, albeit not significant, incidence of major neurologic complications compared to no- $\mathrm{NSH}$ ICUs (Table 2). Moreover, the no-NSH centers of our cohort should not be thought as small units in secondary hospitals. On the contrary, they also included highvolume units delivering multiple specialized services, even in the absence of neurosurgery coverage (Additional file 1: Table S4).

The main limitation of this study is its observational nature. The adopted propensity-score matching methodology is a well-established, robust approach that yields an unbiased estimation of causal effects when the underlying assumptions are satisfied. These assumptions include having measured and considered into the analysis all relevant confounders. Our results could be biased if an unobserved prognostic factor has impacted the decision to admit the patient to no-NSH or NSH ICUs, thus leading to an undetectable imbalance of this variable in the two groups of the matched sample. Even though ruling out the existence of unobserved confounders in our study is impossible, it is unlikely that such confounders have severely biased our estimates. Several well-established 
indicators of severity, related to the severity of brain injury, the baseline conditions and eventual concomitant extracranial traumatic lesions of the patients, have been perfectly balanced in the matched sample. Such indicators include characteristics of the patients measured before the arrival to the hospital and on ICU admission. Moreover, the hypothesis that the overall more favorable 6-month GOS-E of mild patients admitted to no-NSH centers, which is the most original finding of our study, could be due to unobserved confounders, driving undetectably more complex patients to NSH centers, collides with the observed better outcomes of severe TBIs and high-risk patients in NSH centers.

A second significant limitation is NSH and no-NSH centers' definition, used to classify the individual participating ICUs. Such classification partially limits these findings' comparability with studies that classify participating facilities by their trauma care level. Neurosurgery capabilities could also be available in level II TCs, which could have partially influenced the observed results [16]. However, classifying the facilities participating in the study by trauma care level would have been difficult because of the heterogeneity of the trauma systems involved in our international initiative. The same challenges in defining a uniform classification across the countries involved in our project also apply to triage criteria. Notably, given the observational nature of our study, each center maintained the same criteria of the trauma system it refers to.

The unavailability of the ISS score in our data is another aspect to discuss. We were not able to calculate such score because we only collected information on the most severe lesions, as defined by an AIS $>2$. The ISS score has the advantage of ordinally describing lesion severity in separate districts. However, the strategy adopted for describing trauma-related lesions in our prospective data collection includes precise specification of the location and severity of all the serious individual organ lesions of the AIS dictionary (see Additional file 1: Table S2), often occurring simultaneously in the same district. In order to optimally balance the two populations, individual lesions were considered within the matching procedure and, in our opinion, the resulting balance of the matched cohort was not inferior to what could have been achieved by ISSbased matching. Similar observations apply to specific aspects of TBI, considering that patients were matched on numerous variables, including specific intracranial lesions and related volume, Marshall scale, GCS score, and pupil reactivity.

Most ICUs participating in this study were based in Italy (67.5\%, see Additional file 1: Table S4) and, in particular, the proportion of Italian ICUs among no-NSH centers was higher than in the NSH group. Moreover, the characteristics of the no-NSH hospitals in our study may differ from those of the no-NSH centers in other systems. For these reasons, our results should be generalized with caution to very different contexts.

Finally, socioeconomic and rehabilitative factors could have played a role in determining final functional outcome but, due to the high frequency of missing data, these variables were not taken into consideration.

To overcome the limitations of our study and verify the generalizability of its findings, further research is essential. Given the logistic and ethical challenges of randomized trials in this context, such verification needs to rely on specifically designed, prospective observational studies. In particular, to verify whether patients admitted to an ICU in no-NSH hospitals would benefit from treatment in NSH centers, the envisioned study must satisfy two properties. First, the data collection should be carefully planned, to include all variables that may both impact on the outcome of the patient and on the decision of admitting a patient to a NSH or a no-NSH hospital. This is essential to apply rigorous statistical methodology to estimate causal effects on observational data and minimize the risk of unmeasured confounding. Second, the recruitment of the study should aim at minimizing differences in terms of country and even of trauma systems between NSH and no-NSH centers, to minimize the confounding effect of the different contexts where ICUs operate.

\section{Conclusion}

For patients admitted to ICUs without neurosurgical capabilities, we found that admission to NSH centers may be beneficial, in terms of increased survival and higher percentage of good recovery, in the subgroup of patients with severe TBI or at high risk according to the SAPS II score. Conversely, admission to no-NSH centers was associated to higher rates of good recovery and lower mortality in mild TBI and low-risk patients. This unexpected result could have been partially conditioned by greater attention to the management of non-neurologic clinical conditions in no-NSH ICUs, by the adverse effects of more aggressive neuro-oriented therapies performed in the NSH centers, or by the presence of confounders not taken into consideration in the matching procedure.

All in all, this study underlines how the triage of TBI patients to hospitals with different neurosurgical capabilities and facilities could have a marked effect on middleand long-term outcomes. 


\section{Supplementary Information}

The online version contains supplementary material available at https://doi. org/10.1186/s13049-021-00959-2.

Additional file 1. The additional file provides supplementary tables and figures that could not fit in the paper.

\section{Acknowledgements}

The complete list of coauthors is provided below: Sárkány Ágnes (Fejér Megyei Szent György Egyetemi Oktató Kórház, Központi Aneszteziológiai és Intenziv Betegellátó Osztály, Székesfehérvár, Hungary), Fulvio Agostini (A.O.U. Città della Salute e della Scienza di Torino, Servizio Anestesia e Rianimazione 3, Torino, Italy), Claudio Ajmone-Cat (Azienda Ospedaliera San Camillo Forlanini, U.O.C. Shock e Trauma Centro di Rianimazione 1, Roma, Italy), Giovanni Bassi (Ospedale Civico Carrara, Servizio di Anestesia e Rianimazione, Carrara, Italy), Vasileios Bekos (Athens Navy Hospital Intensive Care Unit, Athens, Greece), Marzia Bellin (Ospedale dell'Angelo, Terapia Intensiva Generale, Mestre, Italy), Maria Grazia Bocci (Policlinico Agostino Gemelli, Centro di Rianimazione, Roma, Italy), Valeria Bonato (Civile-SS. Antonio e Biagio e C. Arrigo, Terapia Intensiva e Rianimazione, Alessandria, Italy), Alfeo Bonato (Civil Hospital, Intensive Care Unit, Cittadella, Italy), Manuela Bonizzoli (Azienda Ospedaliero Universitaria Careggi, Terapia Intensiva di Emergenza, Firenze, Italy), Paola Bonucci (Azienda Ospedaliero-Universitaria Senese, Anestesia e Rianimazione DEA e dei Trapianti, Siena, Italy), Andrea Bottazzi (Fondazione IRCCS Policlinico S.Matteo, Rianimazione Polivalente, Pavia, Italy), Giuseppe Calicchio (Azienda Ospedaliera Universitaria San Giovanni di Dio e Ruggi d'Aragona, Centro di Rianimazione, Salerno, Italy), Fabrizia Carlin (Ospedale San Martino, Terapia Intensiva, Belluno, Italy), Sergio Casagli (Azienda Ospedaliera Universitaria Pisana, S.D. Neuroanestesia/Rianimazione, Pisa, Italy), Carlo Alberto Castioni (Ospedale San Giovanni Bosco, Terapia Intensiva, Torino, Italy), Rita Ciceri (Ospedale A. Manzoni, Rianimazione Generale, Lecco, Italy), Francesco Cocciolo (Ospedale Maurizio Bufalini, Anestesia e Rianimazione, Cesena, Italy), Ezio Crestan (Azienda Ospedaliera Ospedale di Lecco, Neurorianimazione II SAR, Lecco, Italy), Peter Cseplo (Petz Aladár Megyei Oktató Kórház, Központi Aneszteziológiai és Intenzív Terápiás Osztály, Győr, Hungary), Francesco Curto (ASST Grande Ospedale Metropolitano Niguarda, Neurorianimazione, Milano, Italy), Wojciech Dąbrowski (University Hospital No 4, Anaesthesiology Intensive Therapy, Lublin, Poland), Anna De Cristofaro (Azienda Ospedali Riuniti Marche Nord Presidio di Pesaro, Struttura Operativa Semplice di Rianimazione, Pesaro, Italy), Izabela Duda (Uniwersyteckie Centrum Kliniczne im. prof. K. Gibińskiego Śląskiego Uniwersytetu Medycznego w Katowicach, Oddział Anestezjologii i Intensywnej Terapii, Katowice, Poland), Or Duek (Ben Gurion University of the Negev, Beer Sheva, Israel), Blanka Emoke Bakó (Bács-Kiskun Megyei Kórház, Központi Aneszteziológia és Intenzív Terápiás Oszzály, Kecskemét, Hungary), Nazzareno Fagoni (Spedali Civili di Brescia, Neurorianimazione, Brescia, Italy), Paola Fassini (Azienda Ospedale Civile di Legnano, Rianimazione, Legnano, Italy), Suada Filekovic (University Medical Centre Ljubljana, Surgical ICU, Lubiana, Slovenia), Gilberto Fiore (Santa Croce-Moncalieri—ASL TO 5, Rianimazione e Terapia Intensiva, Moncalieri, Italy), Emiliano Gamberini (Ospedale Maurizio Bufalini, Unità Operativa di Anestesia e Rianimazione, Cesena, Italy), Diego Gattari (Ospedale Civile, Rianimazione, Macerata, Italy), Massimo Gianni (Ospedale Regionale Umberto Parini, Struttura Complessa di Rianimazione, Aosta, Italy), Maria Giovanna Dessena (Ospedale Giovanni Paolo II, Rianimazione, Olbia, Italy), Romano Giuntini (Ospedale San Giuseppe, Rianimazione, Empoli, Italy), Stefania Guido (AOU Maggiore della Carità, Anestesia e Rianimazione, Novara, Italy), Rita Gyulai (Kenézy Kórház Gyula Kórház és Rendelőintézet, Központi Aneszteziológiai és Intenzív Terápiás Osztály, Debrecen, Hungary), Amir Hadash (Rambam Medical Center, Pediatric Intensive Care Unit, Haifa, Israel), Renata Hribar (Splošna Bolnišnica Novo Mesto, Enota Intenzivne Terapije, Novo Mesto, Slovenia), Stavroula Ilia (University General Hospital of Heraklion Pagni, Intensive Care Unit, Heraklion, Greece), Vesna Novak Jankovic (Clinical Department of Anaesthesiology and Intensive Therapy, University Medical Centre Ljubljana, Slovenia), Vlado Jurekovic (General Hospital Jesenice, Jesenice, Slovenia), Mateja Jereb (Clinical Department of Anaesthesiology and Intensive Therapy, University Medical Centre Ljubljana, Slovenia), Maciej Kapias (Szpital Śląski, Intensive Care Unit, Cieszyn, Poland), Dragica Karadzic (Clinical Department of Anaesthesiology and Intensive Therapy, University Medical Centre Ljubljana, Slovenia), Darja Kasnik (General Hospital Slovenj Gradec,
Department for Anaesthesiology and Intensive Care Medicine, Slovenj Gradec, Slovenia), Anastasios Kioulpalis (Venizeleio-Pananeio General Hospital of Heraklion, Intensive Care Unit, Heraklion, Greece), Adrienn Kitti Szaszi (Borsod-Abaúj-Zemplén Megyei Kórház és Egyetemi Oktató Kórház, Központi Aneszteziológiai és Intenzív Terápiás Osztály, Miskolc, Hungary), Janez Kompan (General Hospital Slovenj Gradec, Department for Anaesthesiology and Intensive Care Medicine, Slovenj Gradec, Slovenia), Eraclis Kyriakides (General Hospital, Nicosia, Cyprus), Sara Lamborghini (Azienda Ospedaliero-Universitaria di Ferrara, Arcispedale S. Anna, Unità Operativa di Anestesia e Rianimazione Ospedaliera, Ferrara, Italy), Sergio Livigni (Ospedale San Giovanni Bosco, Terapia Intensiva, Torino, Italy), Paolo Malacarne (AOUP, Rianimazione / PS, Pisa, Italy), Maria Martelli (AOUP, Rianimazione / PS, Pisa, Italy), Marina Alessandra Martin (San Bortolo, Centro di Rianimazione, Vicenza, Italy), Andrea Marudi (Nuovo Ospedale Civile Sant'Agostino Estense, Rianimazione Neurorianimazione, Modena, Italy), Martina Melis (Ospedale Giovanni Paolo II, Rianimazione, Olbia, Italy), Francesca Mengoli (Department of Integration, Palliative Care Network, Maggiore Hospital, Bologna, Italy), Tomislav Mirkovic (Clinical Department of Anaesthesiology and Intensive Therapy, University Medical Centre Ljubljana, Slovenia), Wiktoria Mizak (Oddział Anestezjologii i Intensywnej Terapii, Szpital Powiatowy Lipsko), Marina Munari (A.O. di Padova, Anestesia e Rianimazione NCH TI, Padova, Italy), Ennio Nascimben (Ospedale Ca'Foncello, Terapia Intensiva Neurochirurgica, Treviso, Italy), Giuseppe Natalini (Fondazione Poliambulanza — Istituto Ospedaliero, Terapia Intensiva Polifunzionale, Brescia, Italy), Giancarlo Negro (Francesco Ferrari, General Intensive Care Unit 1, Casarano, Italy), Csaba Nemes (Fejér Megyei Szent György Egyetemi Oktató Kórház, Központi Aneszteziológiai és Intenzív Betegellátó Oszzály, Székesfehérvár, Hungary), Mara Olga Bernasconi (S. Maria della Misericordia, Terapia Intensiva, Rovigo, Italy), Michele Pagani (Fondazione IRCCS Policlinico S.Matteo, Rianimazione Polivalente, Pavia, Italy), Vieri Parrini (Ospedale del Mugello, Anestesia e Rianimazione, Borgo San Lorenzo, Italy), Panagio Partala (University Hospital Alexandroupolis, Intensive Care Unit, Alexandroupolis, Greece), Mauro Pastorelli (Ospedale E. Agnelli, Rianimazione, Pinerolo, Italy), Isabella Pellicioli (A.O. Papa Giovanni XXIII, Terapia Intensiva Pediatrica, Bergamo, Italy), Paolo Perino Bert (Ospedale di Ciriè, Rianimazione e Terapia Intensiva, Torino, Italy), Nicola Petrucci (Azienda Socio-Sanitaria Territoriale del Garda, Presidio di Desenzano, Rianimazione, Desenzano del Garda, Italy), Simone Piva (Spedali Civili di Brescia, Rianimazione Polifunzionale 2, Brescia, Italy), Daniele Poole (Ospedale San Martino, Terapia Intensiva, Belluno, Italy), Danilo Radrizzani (Azienda Ospedale Civile di Legnano, Rianimazione, Legnano, Italy), Anna Rekas (Wojewódzki Szpital Specjalistyczny,Intensive Care Unit, Lublin, Poland), Paweł Robak (Szpital Miejski im.J.Strusia w Poznaniu, Oddział Anestezjologii i Intensywnej Terapii, Poznan, Poland), Antonio Rosano (Fondazione Poliambulanza-Istituto Ospedaliero, Terapia Intensiva Polifunzionale, Brescia, Italy), Patrizia Ruggeri (Istituti Ospitalieri di Cremona, Terapia Intensiva, Cremona, Italy), Marco Sacchi (ASST Grande Ospedale Metropolitano Niguarda, Neurorianimazione, Milano, Italy), Mara Skoti (Splosna Bolnisnica Izola, Enota Intenzivne Terapije, Izola, Slovenia), Alja Skrt (Splosna Bolnisnica Izola, Enota Intenzivne Terapije, Izola, Slovenia), Ermanno Spagarino (Nuovo Ospedale degli Infermi, Struttura Semplice di Rianimazione e Terapia Intensiva, Ponderano, Italy), Wiktor Sulkowski (Szpital Powiatowy w Ostrowi Mazowieckiej, Anaesthesiology and Intensive Care Department, Ostrów Mazowiecka, Poland), Balázs Szedlák (Borsod-Abaúj-Zemplén Megyei Kórház és Egyetemi Oktató Kórház, Központi Aneszteziológiai és Intenzív Terápiás Osztály, Miskolc, Hungary), Marina Terzitta (G.B. Morgagni-L. Pierantoni, Rianimazione, Forlì, Italy), Rebecca Tinturini (AOU Senese, Anestesia e Terapia Intensiva Neurochirurgia, Siena, Italy), Rossella Tofani (Spedali Riuniti Livorno, Unità Operativa Anestesia e Rianimazione, Livorno, Italy), Paraskevi Tselioti (Tzaneio General Hospital, General Intensive Care Unit, Pireus, Greece), Ada Vecchiarelli (Santa Maria della Misericordia, Unità di Terapia Intensiva, Perugia, Italy), Elisabetta Venturini (Civile-SS. Antonio e Biagio e C. Arrigo, Terapia Intensiva e Rianimazione, Alessandria, Italy), Salvatore Visconti (Ospedale S. Maria di Loreto, Centro di Rianimazione "Marco Pica", Napoli, Italy), Valeria Zompanti (Ospedale Civile, Rianimazione, Macerata, Italy), Roberto Zoppellari (Azienda Ospedaliero—Universitaria di Ferrara, Arcispedale S. Anna, Unità Operativa di Anestesia e Rianimazione Ospedaliera, Ferrara, Italy).

\section{Authors' contributions}

$A G, L G, G C, V B, E F, G i o N$, ArC and $G B$ designed the study. AG, LG, LA, OB, VB, IC, $A K C, A D L, E F, P G, R K, T K, S L, I L, C M, M M, G a N$, GiuN, LP, NX and ArC contributed to the data collection. IC, ADL, SL, CM, GiuN, and LP monitored the data 
collection, with the oversight of GC, JF, GP and GB. GC, GioN and GB were responsible of the statistical analyses. $A G, L G, V B, E F, G i o N, A r C$ and $G B$ drafted the manuscript, and all authors contributed substantially to its revision. All authors read and approved the final manuscript.

\section{Funding}

The study was funded by the European Union Seventh Framework Programme (FP7/2007-2013) under Grant Agreement Number 602714.

\section{Availability of data and materials}

The datasets used and/or analysed during the current study are available from the corresponding author on reasonable request.

\section{Declarations}

\section{Ethics approval and consent to participate}

The Ethics Committee Lazio 1 of the Azienda Ospedaliera San Camillo ForIanini, Rome, Italy, and the local ethics committees at the participating centers approved the study protocol. Written informed consent was obtained from patients or their legal representatives. Where national legislation so permitted and considering the study's observational nature, a waived or delayed consent process was implemented in patients in coma or experiencing high-stress levels.

\section{Consent for publication}

Not applicable.

\section{Competing interests}

ArC reports a patent null pending, outside the submitted work. The other authors declare that they have no other conflict of interest.

\begin{abstract}
Author details
${ }^{1}$ Anesthesia, Intensive Care and Prehospital Emergency, Maggiore Hospital, Bologna, Italy. ${ }^{2}$ Laboratory of Clinical Epidemiology, Department of Public Health, Istituto Di Ricerche Farmacologiche Mario Negri IRCCS, Villa Camozzi, Via G.B. Camozzi 3, 24020 Ranica, Bergamo, Italy. ${ }^{3}$ Orobix, Bergamo, Italy. ${ }^{4}$ Anesthesia and Intensive Care Unit, AUSL Toscana Centro, San Giuseppe Hospital, Empoli, Florence, Italy. ${ }^{5}$ Hungarian Army Medical Center, Budapest, Hungary. ${ }^{6}$ Neurointensive Care Unit, Department of Anesthesia and Intensive Care Unit, AOU Careggi, Florence, Italy. ${ }^{7}$ Clinical Department of Anaesthesiology and Intensive Therapy, University Medical Centre Ljubljana, Ljubljana, Slovenia. ${ }^{8}$ Faculty of Medicine, University of Ljubljana, Ljubljana, Slovenia. ${ }^{9}$ General Hospital Novo Mesto, Novo Mesto, Slovenia. ${ }^{10}$ University of Nicosia Medical School, Nicosia, Cyprus. ${ }^{11}$ University Hospitals Bristol and Weston NHS Foundation Trust, Bristol, UK. ${ }^{12}$ Pediatric Intensive Care Unit, Soroka Medical Center and The Faculty of Health Sciences, Ben-Gurion University of the Negev, Beer Sheva, Israel. ${ }^{13}$ Anesthesia and Intensive Care Unit, AUSL Romagna, Maurizio Bufalini Hospital, Cesena, Italy. ${ }^{14}$ Clinic of Anaesthesia and Intensive Care, Medical University of Warsaw, Warsaw, Poland. ${ }^{15}$ Department of Neurorehabilitation, ASSL Oristano, ATS Sardegna, Oristano, Italy. ${ }^{16}$ Department of Anaesthesiology and Intensive Care, Péterfy Hospital and Trauma Centre, Budapest, Hungary. ${ }^{17}$ Intensive Care Unit, Azienda Socio Sanitaria Territoriale di Lecco, Lecco, Italy. ${ }^{18}$ University Hospital of Heraklion, Crete, Greece. ${ }^{19}$ Neurointensive Care Unit, Grande Ospedale Metropolitano Niguarda, Milan, Italy.
\end{abstract}

Received: 24 May 2021 Accepted: 22 September 2021

Published: 2 November 2021

\section{References}

1. Ghajar J. Traumatic brain injury. Lancet. 2000;356:923-9.

2. Hyder AA, Wunderlich CA, Puvanachandra P, Gururaj G, Kobusingye OC. The impact of traumatic brain injuries: a global perspective. NeuroRehabilitation. 2007;22:341-53.

3. Reilly P. The impact of neurotrauma on society: an international perspective. Prog Brain Res. 2007;161:3-9.

4. Rubiano AM, Carney N, Chesnut R, Puyana JC. Global neurotrauma research challenges and opportunities. Nature. 2015;527:S193-7.
5. Bill F, Foundation MG. Global, regional, and national burden of stroke, 1990-2016: a systematic analysis for the Global Burden of Disease Study. Lancet Neurol. 2016;18:439-58.

6. Madhok DY, Yue JK, Sun X, Suen CG, Coss NA, Jain S, et al. Clinical predictors of 3- and 6-month outcome for mild traumatic brain injury patients with a negative head CT scan in the emergency department: a TRACK-TBI pilot study. Brain Sci. 2020;10:1-15.

7. Triebel KL, Martin RC, Novack TA, Dreer LE, Turner C, Kennedy R, et al. Recovery over 6 months of medical decision-making capacity after traumatic brain injury. Arch Phys Med Rehabil. 2014;95:2296-303.

8. Wright DW, Kellermann A, McGuire LC, Chen B, Popovic T. Prevention P. CDC grand rounds: reducing severe traumatic brain injury in the United States. MMWR. 2013;62:549-52.

9. Utter GH, Maier RV, Rivara FP, Mock CN, Jurkovich GJ, Nathens AB. Inclusive trauma systems: do they improve triage or outcomes of the severely injured? J Trauma Inj Infect Crit Care. 2006;60:529-37.

10. Sturms LM, Hoogeveen JM, Le Cessie S, Schenck PE, Pahlplatz PVM, Hogervorst $\mathrm{M}$, et al. Prehospital triage and survival of major trauma patients in a Dutch regional trauma system: relevance of trauma registry. Langenbeck's Arch Surg. 2006;391:343-9.

11. Esposito TJ. Neurosurgeons, acute care surgeons or moms: who should care for the head injured? J Trauma Treat. 2012;1 (6):137-42.

12. Thompson HJ, Rivara FP, Jurkovich GJ, Wang J, Nathens AB, Mackenzie EJ. Evaluation of the effect of intensity of care on mortality after traumatic brain injury. Crit Care Med. 2008;36:282-90.

13. Gerber LM, Chiu YL, Carney N, Härtl R, Ghajar J. Marked reduction in mortality in patients with severe traumatic brain injury: clinical article. J Neurosurg. 2013;119:1583-90.

14. Clement RC, Carr BG, Kallan MJ, Wolff C, Reilly PM, Malhotra NR. Volume-outcome relationship in neurotrauma care. J Neurosurg. 2013;118:687-93.

15. Oberholzer M, Müri RM. Neurorehabilitation of traumatic brain injury (TBI): a clinical review. Med Sci. 2019;7:47.

16. Chieregato A, Volpi A, Gordini G, Ventura C, Barozzi M, Caspani MLR, et al. How health service delivery guides the allocation of major trauma patients in the intensive care units of the inclusive (hub and spoke) trauma system of the Emilia Romagna Region (Italy). A cross-sectional study. BMJ Open. 2017;7:e016415.

17. Jennett B, Snoek J, Bond MR, Brooks N. Disability after severe head injury: observations on the use of the glasgow outcome scale. J Neurol Neurosurg Psychiatry. 1981;44:285-93.

18. CREACTIVE: welcome to the CREACTIVE project [Internet]. [cited 2020 Oct 23]. http://creactive.marionegri.it/

19. Leppäniemi A. Trauma systems in Europe. Curr Opin Crit Care. 2005;11:576-9.

20. Finazzi S, Paci G, Antiga L, Brissy O, Carrara G, Crespi D, et al. Prosafe: A european endeavor to improve quality of critical care medicine in seven countries. Minerva Anestesiol Ed Minerva Med. 2020;86:1305-20.

21. Vandenbroucke JP, von Elm E, Altman DG, Gøtzsche PC, Mulrow CD, Pocock SJ, et al. Strengthening the reporting of observational studies in epidemiology (STROBE): explanation and elaboration. PLoS Med. 2007:4:e297.

22. Rosenbaum PR. Optimal matching for observational studies. J Am Stat Assoc. 1989;84:1024-32.

23. Stuart EA. Matching methods for causal inference: a review and a look forward. Stat Sci. 2010;25:1-21.

24. Rosenbaum PR, Rubin DB. The central role of the propensity score in observational studies for causal effects. Biometrika. 1983;70:41-55.

25. Hansen BB, Olsen KS. Optimal full matching and related designs via network flows. J Comput Graph Stat. 2006;15:609-27.

26. Kaufman EJ, Ertefaie A, Small DS, Holena DN, Delgado MK. Comparative effectiveness of initial treatment at trauma center vs neurosurgery-capable non-trauma center for severe, isolated head injury. J Am Coll Surg. 2018:226:741-751.e2.

27. Nijboer JMM, Van Der Sluis CK, Dijkstra PU, Ten Duis HJ. The value of the trauma mechanism in the triage of severely injured elderly. Eur J Trauma Emerg Surg. 2009;35:49-55.

28. Yoder A, Bradburn EH, Morgan ME, Vernon TM, Bresz KE, Gross BW, et al. An analysis of overtriage and undertriage by advanced life support transport in a mature trauma system. J Trauma Acute Care Surg. 2020:88:704-9 
29. Voskens FJ, Van Rein EAJ, Van Der Sluijs R, Houwert RM, Lichtveld RA, Verleisdonk EJ, et al. Accuracy of prehospital triage in selecting severely injured trauma patients. JAMA Surg. 2018;153:322-7.

30. Schellenberg M, Benjamin E, Bardes JM, Inaba K, Demetriades D. Undertriaged trauma patients: who are we missing? J Trauma Acute Care Surg. 2019;87:865-9.

31. Doumouras AG, Haas B, Gomez D, De Mestral C, Boyes DM, Morrison L, et al. The impact of distance on triage to trauma center care in an urban trauma system. Prehospital Emerg Care. 2012;16:456-62.

32. Chalouhi N, Mouchtouris N, Al Saiegh F, Starke RM, Theofanis T, Das SO, et al. Comparison of outcomes in level I vs Level II trauma centers in patients undergoing craniotomy or craniectomy for severe traumatic brain injury. Neurosurgery. 2020;86:107-11.

33. Ernstberger A, Koller M, Zeman F, Kerschbaum M, Hilber F, Diepold E, et al. A trauma network with centralized and local health care structures: Evaluating the effectiveness of the first certified Trauma Network of the German Society of Trauma Surgery. PLoS ONE. 2018;13:1-21.

34. Harrison DA, Prabhu G, Grieve R, Harvey SE, Sadique MZ, Gomes M, et al. Risk Adjustment In Neurocritical care (RAIN) — prospective validation of risk prediction models for adult patients with acute traumatic brain injury to use to evaluate the optimum location and comparative costs of neurocritical care: a cohort study. Health Technol Assess (Rockv). 2013;17:vii-350

35. Nishijima DK, Gaona SD, Faul M, Tancredi DJ, Waechter T, Maloney R, et al. The association of trauma center transport and long-term functional outcomes in head-injured older adults transported by emergency medical services. Acad Emerg Med. 2020;27:207-16.

\section{Publisher's Note}

Springer Nature remains neutral with regard to jurisdictional claims in published maps and institutional affiliations.

- fast, convenient online submission

- thorough peer review by experienced researchers in your field

- rapid publication on acceptance

- support for research data, including large and complex data types

- gold Open Access which fosters wider collaboration and increased citations

- maximum visibility for your research: over $100 \mathrm{M}$ website views per year

At BMC, research is always in progress.

Learn more biomedcentral.com/submissions 